\title{
Antidiabetic and Antioxidant Activity of Coccinea grandis Voigt Stem Extract in Streptozotocin Induced Diabetic Rats
}

\author{
Momin Yasmin Hamid ${ }^{*}$, Yeligar Veerendra Channabasappa ${ }^{2}$ \\ ${ }^{1}$ Department of Pharmaceutical Chemistry, Annasaheb Dange College of B. Pharmacy, Ashta, 416301, Maharashtra, India. \\ 2 Department of Pharmaceutical Chemistry `Oxford College of Pharmacy, Bangalore, Karnataka, India.
}

\begin{abstract}
Objective: In the present study, the antidiabetic and antioxidant study of stem part of Coccinea grandis Voigt plant extracts in Streptozotocin induced diabetic rats were investigated. Materials and methods: Fifty four Wistar albino rats were used with nine groups and with six rats in each group. $45 \mathrm{mg} / \mathrm{kg}$ body weight streptozotocin was administered to group 2 to 9. Group 2 was diabetic control. Group 3 was given with glimepiride as standard drug. Group 4 and 5 were given petroleum ether extract 250 and $500 \mathrm{mg} / \mathrm{kg}$ respectively. Group 6 and 7 were given 250 and $500 \mathrm{mg} / \mathrm{kg}$ chloroform extract respectively. Group 8 and 9 were given 250 and 500 mg/kg hydro alcoholic extract respectively. Antidiabetic activity of the extracts was assessed by serum glucose level on glucose kit. Superoxide dismutase (SOD), Catalase (CAT) and lipid peroxidation studies were assessed with histopathology. Result: The chronic study data on diabetic rats cleared the administration of all extracts significantly reduced blood glucose level and lipid peroxidation level with better antioxidant activity. Conclusion: From the study, the petroleum ether, chloroform and hydro alcoholic extracts of stem part of Coccinea grandis Voigt plant have shown antidiabetic and antioxidant potential.
\end{abstract}

Keywords: Antidiabetic activity, antioxidant activity, Lipid peroxidation, Superoxide dismutase, Catalase.

Article Info: Received 12 July 2019; Review Completed 20 Aug 2019; Accepted 23 Aug 2019; Available online 30 Aug 2019

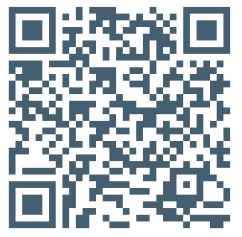

\section{Cite this article as:}

Momin YH, Yeligar VC, Antidiabetic and Antioxidant Activity of Coccinea grandis Voigt Stem Extract in Streptozotocin Induced Diabetic Rats, Journal of Drug Delivery and Therapeutics. 2019; 9(4-A):390-395

http://dx.doi.org/10.22270/jddt.v9i4-A.3438

Momin Yasmin Hamid, Department of Pharmaceutical Chemistry, Annasaheb Dange College of B. Pharmacy, Ashta, Sangli, Maharashtra India 416301.

\section{INTRODUCTION}

Diabetes mellitus is a metabolic disorder characterized by deficient blood insulin level. This may be cause because of lack of sensitivity of receptors to the insulin or autoimmune destruction of pancreatic $ß$ cells of Langerhans which leads to abnormal glucose homeostasis and elevated blood glucose level.[1] Insulin is a hormone secreted in pancreas which allows body to use glucose as a source of energy. Insulin helps to maintain blood glucose level within the normal limit. [2]

According to WHO survey in 2016, 422 million adults are living with diabetes mellitus globally. In India, more than 62 million people suffered by diabetes mellitus. By 2030, it was predicted that 79.4 million people would be diabetic in India. The prevalence of diabetes is more in India due to changes in lifestyle, trend of urbanization, global nutrition transition, genetic factor, environmental influences, rising living standards. Diabetes mellitus is categorized into mainly two types. Type I Diabetes mellitus (Insulin dependent DM) and type II Diabetes mellitus (Non-insulin dependent DM). [3] Amongst these types, $90 \%$ people are having type II Diabetes mellitus. (National diabetes Fact Sheet 2005). [4]

Diabetes mellitus is one of the fatal disorders in the world and it is an $6^{\text {th }}$ leading cause of death. [5]The death rate in diabetic people is double to that of normal people. Diabetes mellitus affects many major organs of body. Many complications are associated with diabetes mellitus. It can cause kidney failure, blindness, impotence, cerebrovascular disorder, cardiovascular disorder.

Medicinal plants have become useful remedies for the treatment of diabetes mellitus and its complication because of polyphenol [6], saponins glycosides, flavonoids, sterol constituents present in the plants have ability to reduce the blood glucose level and cholesterol level. It has been described in ancient literature about the use of natural medicinal plants or herbal products in diabetes mellitus. Antidiabetic effect of these plants is may be due to their ability to recover the disturbed function of pancreas or 
decreases the intestinal glucose absorption. Reported data shown that more than 800 plants possess antidiabetic potential. [7] The plants consist of phytoconstituents like saponins, flavonoids, alkaloids, glycosides, and sterol. These phytoconstituents contribute various medicinal properties. From experimental studies it seems that medicinal plants have potential to reduce blood glucose level or delay the complications associated with diabetes mellitus. The isolated and optimized phytoconstituents from the plants could serve as a better candidate in drug discovery for diabetes. [8]

Many research studies growing in the field of herbal medicine in the past few decades. Research studies in the isolation of phytoconstituents showing therapeutic effect on various diseases have become good approach in herbal area. WHO has suggested efficiency of phytochemicals in reducing blood glucose level and hence its use in the treatment of diabetes mellitus.

Coccinea grandis Voigt is a perennial creeper or climber plant belongs to Cucurbitaceae family. It is commonly known as Ivy gourd or scarlet gourd or kowai fruit or kundru. This plant grows up to $13 \mathrm{~cm}$ in height covering small trees, poles, buildings. It consists of 5 lobed glabrous, broad leaves which is 5 to $10 \mathrm{~cm}$ in length. The upper surface of leaves is hairless while lower surface is hairy with heart or pentagon shape. It consists of single tendrils. Immature fruit of Coccinea grandis contains white streaks and complete ripe fruit is of bright scarlet. Seeds are rounded at apex, yellowish grey in color, ovoid and compressed. Flowers are 2-3 cm long, Female and male flowers emerge at axils on petiole and contain 3 stamens. Coccinea grandis has long, thick, tuberous root with fibrous fracture.[9] The stem of these plants are smooth, green in color and slender when young but as it grows it becomes broad, swollen and glabrous in nature. Various parts of Coccinea grandis Voigt have been used to treat diabetes mellitus, [10] bronchitis, urinary tract infection, ulcer, microbial infection, oxidative stress. The leaf part of Coccinea grandis Voigt has antioxidant property. [9]

$\begin{array}{ll}\text { Kingdom } & \text { Plantae } \\ \text { Order } & \text { Cucurbitales } \\ \text { Family } & \text { Cucurbitaceae } \\ \text { Subfamily } & \text { Cucurbitoideae } \\ \text { Tribe } & \text { Benincaseae } \\ \text { Genus } & \text { Coccinea Voigt }\end{array}$

Leaves extract of Coccinea grandis reduces blood glucose level in Volunteers. [11] Hydro alcoholic leaves extract of Coccinea Grandis plant also reduces blood glucose level in diabetes induced rats.

Dried extract of whole plant of Coccinea grandis shows antidiabetic activity in diabetic dogs. Alcoholic and aqueous extract of root powder Coccinea grandis shows hypoglycemic activity in rabbits. [12] The mucilage isolated from fruit extract of Coccinea indica plant exhibit good antioxidant property. [13]

The antidiabetic activity of Coccinea grandis Voigt plant of leaves, fruit, whole part, root part was documented. Present study has been made to explore antidiabetic activity of stem extract of Coccinea grandis Voigt plant in streptozotocin induced diabetes mellitus.

\section{MATERIALS AND METHODS}

\subsection{Drugs and Chemicals}

Analytical grade chemicals of Loba chemie for extraction were purchased from unique chemicals Kolhapur. Streptozotocin (Sigma Aldrich) and glimepiride were procured for the study from Kolhapur. Commercial reagents kits were used for biochemical estimation.

\subsection{Plant material}

The stem part of Coccinea grandis Voigt was collected from Ashta, Sangli and adjacent villages of Sangli in the month of October. The authentication of plant was carried out from Botanical Survey of India Pune. The voucher specimen number is BSI/WRC/IDEN.CER./2019/H3/138.The stem was cut into small pieces and dried under shade for 10 to 15 days.

\subsection{Preparation of extract}

The dried pieces of stem of plant were crushed in an electrical grinder and made coarse powder for further extraction. $2 \mathrm{~kg}$ coarse powder was subjected to continuous hot soxhlet extraction by using petroleum ether, chloroform and ethyl acetate respectively. The filtrate obtained from continuous hot extraction of each solvent was evaporated to dryness. Further obtained marc was macerated by using methanol and water. Filtrate was evaporated to dryness. The yields of petroleum ether, chloroform, ethyl acetate and water methanol extracts were 16 gm., 13 gm., 8 gm. and 10 gm. respectively. These extracts were stored at $0-40 \mathrm{C}$. in the refrigerator.

\subsection{Experimental animals}

Wistar albino rats weighing 200-300 g were obtained from the central animal house of H. S. K. College of Pharmacy and Research Centre, Bagalkot. The animals were housed at room temperature $(22-28 \stackrel{\circ}{\circ})$ with $65 \pm 10 \%$ relative humidity for $12 \mathrm{hr}$. dark and light cycle and given standard laboratory feed and water ad libitum. The study was approved and conducted as per the norms of the Institutional Animal Ethics Committee (Appasaheb Birnale College of Pharmacy, Sangli) on 22 January 2018. Reference No. IAEC/ABCP/08/2017-18.

\subsection{Acute toxicity study (LD50)}

The acute toxicity of Coccinea grandis stem extracts were studied according to the OECD guidelines 425 and the female Swiss albino mice (25-30g) were used for acute toxicity. Lethal dose (LD50) was calculated with the help of acute oral toxicity (AOT) software. Based on the result of the study, the screening doses of extracts selected for activity. The extracts found to be safe and found no mortality at $2000 \mathrm{mg} / \mathrm{kg}$ body weight in female mice. Dose selected for the activity were $250 \mathrm{mg} / \mathrm{kg}$ and $500 \mathrm{mg} / \mathrm{kg}$.BW.

\subsection{Oral Glucose Tolerance Test (OGTT)}

The acclimatized animals were fasted for 24 hours with water ad libitum, fasted animals were

divided into seven groups. The dose administered after withdrawing the 0 hours of blood sample and at an interval of $1 \frac{1}{2}, 3,5$ hours after the $250 \mathrm{mg} / \mathrm{kg}$ and $500 \mathrm{mg} / \mathrm{kg}$ administration. Blood samples were collected from retroorbital plexus under anesthesia and were centrifuged at $3000 \mathrm{rpm}$ for 10 minutes to obtain the serum, and used for estimation of glucose by using glucose kit. 


\subsection{Induction of Experimental Diabetes}

After 1 week of acclimatization, the rats were subjected to a 16-h fast. Diabetes was induced with a single injection of streptozotocin (STZ) $45 \mathrm{mg} / \mathrm{kg}$ body weight by intraperitoneal route[14]Initial drug induced hypoglycemia was reduced by giving $20 \%$ glucose solution overnight. After 5 days the of streptozotocin injection, the fasting blood glucose level above $250 \mathrm{mg} / \mathrm{dL}$ was taken as diabetic. [15]

\subsection{Experimental design}

In the experiment, a total of 54 rats (6 normal; 48 STZ diabetic rats) were used. The rats were divided into 9 groups of 6 animals each.

\section{Treatment group:}

1. Group-I: Control rats were administered with 0.5 $\mathrm{mL}$ of $0.9 \%$ saline orally [Non-diabetic].

2. Group-II: Streptozotocin ( $45 \mathrm{mg} / \mathrm{kg}$ body weight) induced diabetic rats.

3. Group III: Standard drug Glimepiride $(10 \mathrm{mg} / \mathrm{kg}$ body weight) was given to diabetic rats[16]

4. Group-IV: $250 \mathrm{mg} / \mathrm{kg}$ of Petroleum ether extract was given to diabetic rats.

5. Group-V: $500 \mathrm{mg} / \mathrm{kg}$ of Petroleum ether extract was given to diabetic rats.

6. Group-VI: $250 \mathrm{mg} / \mathrm{kg}$ of Chloroform extract was given to diabetic rats.

7. Group-VII: $500 \mathrm{mg} / \mathrm{kg}$ of Chloroform ether extract was given to diabetic rats.

8. Group-VIII: $250 \mathrm{mg} / \mathrm{kg}$ of Hydro alcoholic extract was given to diabetic rats.

9. Group-IX: $500 \mathrm{mg} / \mathrm{kg}$ of Hydro alcoholic extract was given to diabetic rats.

Above treatment was given for 14 days orally.

\subsection{Biochemical Estimation}

\subsubsection{Measurement of blood glucose level}

The blood glucose levels of rats were measured after 5 days, 10 days and 14 days by using Glucose oxidase-peroxidase (GOD -POD) estimation kit method.

\subsubsection{Lipid peroxidation (LPO)}

Thiobarbituric acid reactive substances (TBARS) in the homogenate were estimated by using Fraga et al. (1981) [17] method. Briefly, the $0.5 \mathrm{ml}$ of $10 \%$ homogenate, $0.5 \mathrm{ml}$ saline and $1.0 \mathrm{ml} 10 \%$ TCA were mixed well and centrifuged at $3000 \mathrm{rpm}$ for 20 minutes. In $1 \mathrm{ml}$ protein free supernatant solution, $0.25 \mathrm{ml}$ of Thiobarbituric acid was added, mixed well and boiled for 1 hour at $95^{\circ} \mathrm{C}$. The absorption was measured at $532 \mathrm{~nm}$. The amount of lipid peroxidation was expressed as TBARS nmoles /mg of protein.

\subsubsection{Superoxide dismutase (SOD)}

Superoxide dismutase activity was determined based on the ability of SOD to inhibit the auto-oxidation of epinephrine to adrenochrome at alkaline $\mathrm{pH}$.

$25 \mu \mathrm{L}$ of the supernatant solution obtained from the centrifuged liver homogenate was first added to $50 \mathrm{mM}$ sodium carbonate buffer (10.2) Then $0.1 \mathrm{mM}$ epinephrine was added in a total volume of $2 \mathrm{ml}$ of buffer medium. Absorption was measured at $480 \mathrm{~nm}$. The SOD activity was calculated in terms of (U/mg of protein). [18]

\subsubsection{Catalase (CAT)}

The assay mixture consisted of $1.95 \mathrm{ml}$ phosphate buffer $(0.05 \mathrm{M}, \mathrm{pH} 7.0), 1.0 \mathrm{ml}$ hydrogen peroxide $(0.019 \mathrm{M})$, and $0.05 \mathrm{ml}$ homogenate $(10 \%, \mathrm{w} / \mathrm{v})$ in a total volume of $3.0 \mathrm{ml}$ changes in absorbance were recorded at $240 \mathrm{~nm}$. Catalase activity was calculated in terms of units /mg protein. [19]

\subsection{Histopathology}

The pancreas from each group was dissected out and placed in $10 \%$ buffered neutral formal saline solution and then used. Then these tissues were embedded in paraffin. These fixed tissues were cut and stained with eosin and hematoxylin. The tissue section was observed under microscope. [20]

\subsection{Statistical analysis}

All data was expressed as mean \pm SEM. The results were analyzed by one way analysis of variance (ANOVA) followed by Dunnet's test. The significant levels were $p<0.05, p<0.01$, and $\mathrm{p}<0.001$.

\subsection{RESULTS}

The acute toxicity study showed the non-toxicity of Coccinea grandis Voigt plant extracts. The lower dose of $250 \mathrm{mg} / \mathrm{kg}$ and higher dose of $500 \mathrm{mg} / \mathrm{kg}$ were selected for antidiabetic study.

Table no. 1 showed the effect of petroleum ether, chloroform and hydro alcoholic extracts on blood glucose level of normal group of Wistar albino rats after 0 hrs., 1 1/2 hrs., 3 hrs.and5hrs.

Table 1: Effect of Petroleum ether, Chloroform and Hydro alcoholic extracts on normal group (hypoglycemic activity)

\begin{tabular}{|l|l|l|l|l|l|}
\hline \multirow{2}{*}{ Sr. no } & \multirow{2}{*}{ Treatment } & \multicolumn{4}{|l|}{ Serum (blood)glucose levels in mg/dl with } \\
\cline { 3 - 6 } & & 0 hrs. & $11 / 2 \mathrm{hrs}$. & $3 \mathrm{hrs}$. & $5 \mathrm{hrs}$. \\
\hline 1 & Normal & $94.17 \pm 2.226$ & $95.78 \pm 2.262$ & $93.22 \pm 1.934$ & $95.31 \pm 2.764$ \\
\hline 2 & Petroleum ether extract-250mg/kg & $89.51 \pm 3.131$ & $80.36 \pm 3.625^{* * *}$ & $74.43 \pm 3.214^{* * *}$ & $61.03 \pm 2.897^{* * *}$ \\
\hline 3 & Petroleum ether extract-500 $\mathrm{mg} / \mathrm{kg}$ & $99.87 \pm 2.429$ & $86.96 \pm 1.70$ & $77.40 \pm 2.085^{* * *}$ & $63.52 \pm 2.682^{* * *}$ \\
\hline 4 & Chloroform extract- $250 \mathrm{mg} / \mathrm{kg}$ & $100.4 \pm 2.923$ & $88.20 \pm 2.210^{*}$ & $79.43 \pm 4.026^{* *}$ & $62.54 \pm 3.383^{* * *}$ \\
\hline 5 & Chloroform extract-500 $\mathrm{mg} / \mathrm{kg}$ & $99.2 \pm 2.153$ & $91.10 \pm 2.231^{*}$ & $82.13 \pm 3.153^{* *}$ & $71.21 \pm 3.426^{* * *}$ \\
\hline 6 & Me-water-Extract- $250 \mathrm{mg} / \mathrm{kg}$ & $87.65 \pm 2.131$ & $84.21 \pm 2.241^{*}$ & $92.12 \pm 3.141^{* *}$ & $96.31 \pm 3.432^{* * *}$ \\
\hline 7 & Me-water-Extract-500 $\mathrm{mg} / \mathrm{kg}$ & $91.21 \pm 2.5723$ & $85.12 \pm 2.362^{*}$ & $89.12 \pm 3.146^{* *}$ & $84.51 \pm 3.471^{* * *}$ \\
\hline
\end{tabular}

All value are expressed as mean \pm SEM, $\mathrm{n}=6$ in each, ${ }^{*} P<0.05,{ }^{* *} P<0.01,{ }^{* * *} P<0.001$ as (paired t test) compared to 0 hour within the group. The values in parentheses represent $\%$ change glycemic index. 
There was reduction in blood glucose level appeared in normal rats.

Effect of petroleum ether, chloroform and hydro alcoholic extracts on blood glucose level of streptozotocin induced diabetic rats after 3,5,10 and 14 day were shown in table no.2.

Table. No. 2. Effect of Petroleum ether, Chloroform and Hydro alcoholic extracts on streptozotocin induced diabetic rats (Chronic study)

\begin{tabular}{|c|c|c|c|c|c|}
\hline \multirow[t]{2}{*}{ Sr. no } & \multirow[t]{2}{*}{ Treatment } & \multicolumn{4}{|c|}{ Serum glucose levels in mg/dl } \\
\hline & & $3^{\text {rd day }}$ & $5^{\text {th }}$ day & $10^{\text {st }}$ day & $14^{\text {th }}$ day \\
\hline 1 & Normal & $97.91 \pm 6.296$ & $101.9 \pm 6.425$ & $95.80 \pm 5.975$ & $99.74 \pm 6.223$ \\
\hline 2 & Control & $340.5 \pm 9.107 \mathrm{a}$ & $331.0 \pm 9.599 a$ & $334.1 \pm 9.088^{\mathrm{a}}$ & $318.5 \pm 10.54^{a}$ \\
\hline 3 & $\begin{array}{l}\text { Petroleum ether } \\
\text { extract-250mg/kg }\end{array}$ & $318.0 \pm 14.69$ & $225.9 \pm 9.819^{* * *}$ & $142.0 \pm 14.44^{* * *}$ & $97.30 \pm 4.271^{* * *}$ \\
\hline 4 & $\begin{array}{l}\text { Petroleum ether } \\
\text { extract-500 mg/kg }\end{array}$ & $284.4 \pm 28.37$ & $246.5 \pm 29.65^{* *}$ & $150.2 \pm 16.70^{\text {*** }}$ & $109.5 \pm 5.902^{* * *}$ \\
\hline 5 & $\begin{array}{l}\text { Chloroform extract- } \\
250 \mathrm{mg} / \mathrm{kg}\end{array}$ & $293.5 \pm 25.62$ & $258.2 \pm 17.88^{*}$ & $187.8 \pm 25.98^{* * *}$ & $137.0 \pm 12.78^{* * *}$ \\
\hline 6 & $\begin{array}{l}\text { Chloroform extract- } \\
500 \mathrm{mg} / \mathrm{kg}\end{array}$ & $282.1 \pm 25.62$ & $232.2 \pm 14.71^{*}$ & $175.1 \pm 10.92^{* * *}$ & $128.0 \pm 11.62^{* * *}$ \\
\hline 7 & $\begin{array}{l}\text { Me-water-Extract- } \\
250 \mathrm{mg} / \mathrm{kg}\end{array}$ & $261.23 \pm 12.41^{* *}$ & $221.1 \pm 11.21^{* * *}$ & $156.2 \pm 14.45^{* * *}$ & $119.02 \pm 11.58^{* * *}$ \\
\hline 8 & $\begin{array}{l}\text { Me-water-Extract- } \\
500 \mathrm{mg} / \mathrm{kg}\end{array}$ & $224.17 \pm 9.21^{* *}$ & $169.1 \pm 13.11^{* * *}$ & $135.1 \pm 11.27^{* * *}$ & $115.12 \pm 09.11^{*}$ \\
\hline 9 & $\begin{array}{l}\text { Glimepiride } \\
\text { (10mg/kg) }\end{array}$ & $198.5 \pm 12.20^{* *}$ & $188.0 \pm 4.898^{* *}$ & $149.4 \pm 4.413^{* * *}$ & $90.26 \pm 5.203^{* * *}$ \\
\hline
\end{tabular}

All value are expressed as mean \pm SEM, $\mathrm{n}=6$ in each, a $P<0.01$ as compared to normal group, ${ }^{*} P<0.05,{ }^{* *} P<0.01$, ${ }^{* * *} P<0.001$ ascompared to control group. One way ANOVA followed by Dunnet's test. The values in parentheses represent $\%$ change glucose level.

Glimepiride $10 \mathrm{mg} / \mathrm{kg}$ body weight was used standard. The study showed the reduction in blood glucose level in diabetic rats. Table No.3. Showed the effect of Petroleum ether, Chloroform and Hydro alcoholic extracts on SOD, CAT and lipid peroxidation. The lipid peroxidation was decreased whereas the SOD and CAT values were increased to the normal.

Table. No. 3. Effect of Petroleum ether, Chloroform and Hydro alcoholic extracts on biochemical parameters

\begin{tabular}{|c|c|c|c|c|}
\hline \multirow[t]{2}{*}{ Sr. no } & \multirow[t]{2}{*}{ Treatment } & \multicolumn{3}{|c|}{ BIOCHEMICAL MARKERS [14th day] } \\
\hline & & $\begin{array}{l}\text { SOD } \\
\text { (U/mg of protein) }\end{array}$ & $\begin{array}{l}\text { Catalase } \\
\text { (U/mg of protein) }\end{array}$ & $\begin{array}{l}\text { Lipid peroxidation } \\
\text { (nmoles/mg of protein) }\end{array}$ \\
\hline 1 & Normal & $542.9 \pm 41.1$ & $0.185 \pm 0.022$ & $89.00 \pm 8.05$ \\
\hline 2 & Control & $311.2 \pm 33.42$ & $0.014 \pm 0.017 \mathrm{a}$ & $563.7 \pm 9.90^{a}$ \\
\hline 3 & $\begin{array}{l}\text { Petroleum ether extract- } \\
250 \mathrm{mg} / \mathrm{kg}\end{array}$ & $726.4 \pm 22.51$ & $0.178 \pm 0.019^{* * *}$ & $163.8 \pm 2.73^{* * *}$ \\
\hline 4 & $\begin{array}{l}\text { Petroleum ether extract- } \\
500 \mathrm{mg} / \mathrm{kg}\end{array}$ & $894.1 \pm 221.3$ & $0.209 \pm 0.020^{* * *}$ & $158.2 \pm 7.20^{* * *}$ \\
\hline 5 & $\begin{array}{l}\text { Chloroform extract-250 } \\
\mathrm{mg} / \mathrm{kg}\end{array}$ & $1041 \pm 44.1^{*}$ & $0.333 \pm 0.041^{* * *}$ & $173.1 \pm 2.20^{* * *}$ \\
\hline 6 & $\begin{array}{l}\text { Chloroform extract-500 } \\
\mathrm{mg} / \mathrm{kg}\end{array}$ & $1061 \pm 36.1^{*}$ & $0.357 \pm 0.051^{* * *}$ & $189.1 \pm 4.50^{* * *}$ \\
\hline 7 & $\begin{array}{l}\text { Me-water-Extract- } 250 \\
\mathrm{mg} / \mathrm{kg}\end{array}$ & $689 \pm 12.2^{*}$ & $0.145 \pm 0.045^{* * *}$ & $198.2 \pm 3.25^{* * *}$ \\
\hline 8 & $\begin{array}{l}\text { Me-water-Extract-500 } \\
\mathrm{mg} / \mathrm{kg}\end{array}$ & $783 \pm 10.2^{*}$ & $0.132 \pm 0.015^{* * *}$ & $210.1 \pm 2.11^{* * *}$ \\
\hline 10 & Glimepiride 4mg/kg & $317 \pm 21.3$ & $0.142 \pm 0.011^{* *}$ & $178.1 \pm 2.22^{* * *}$ \\
\hline
\end{tabular}

All value are expressed as mean \pm SEM, $\mathrm{n}=6$ in each, a $P<0.001$ as compared to normal group; ${ }^{*} P<0.05,{ }^{* *} P<0.01,{ }^{* * *} P<0.001$ as compared to control group. One way ANOVA followed by Dunnet's test. 
Histopathological observations of Coccinea grandis Voigt plant extracts $(250 \mathrm{mg} / \mathrm{kg}$ and $500 \mathrm{mg} / \mathrm{kg}$ ) treated for 14 days in streptozotocin induced diabetic rat pancreas of different groups were shown in fig 1.

\section{Fig.No.1. Histopathological study}

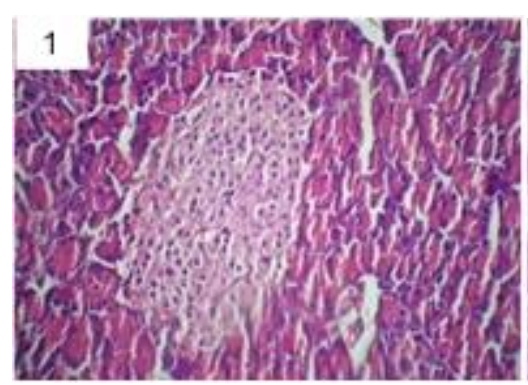

Normal (A)

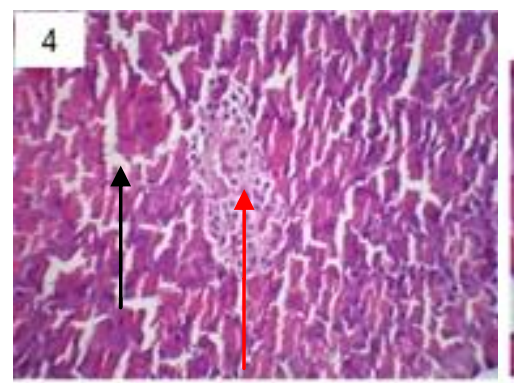

$500 \mathrm{mg} / \mathrm{kg}$ Pet ether (D)

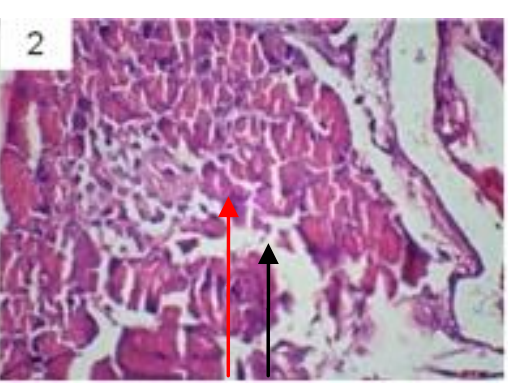

STZ 45mg/kg (B)

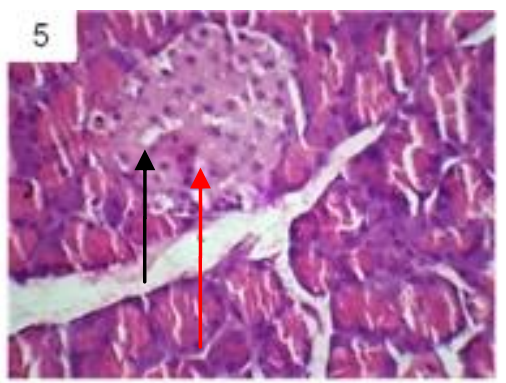

$500 \mathrm{mg} / \mathrm{kg}$ Chl. Extract (E)

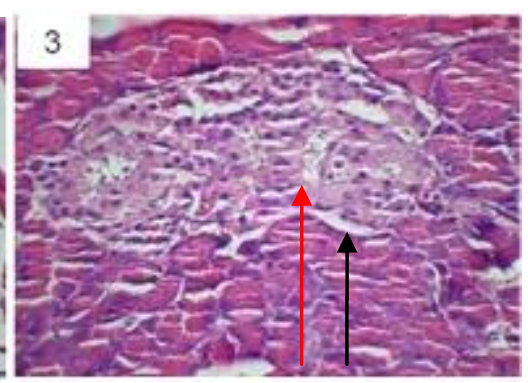

Glimepiride 4mg/kg (C)

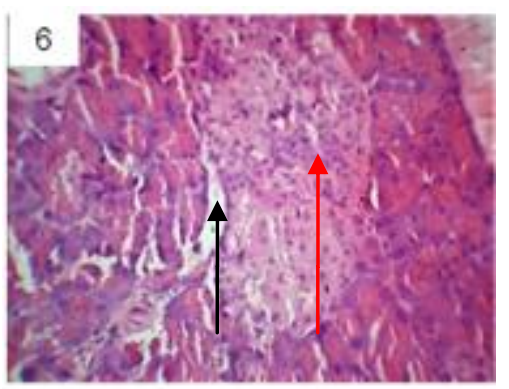

$500 \mathrm{mg} / \mathrm{kg}$ of Hydro Alcoholic extract (F)

Fig 1. Normal (A): Showed normal pancreatic architecture, no intracellur gap and density of cells normal. Control (B): STZ given animals showed complete destruction of pancreas, intracellular gap, decreased cell density and altered architecture. Glimepiride (C) and extracts: D, E, F Indicated the decreased intracellular gap, regain of architecture and increased density of cells.

\subsection{DISCUSSION}

Streptozotocin (45 mg/kg body weight) was used for inducing diabetes in Wistar albino rats.

Acute toxicity studies showed the non-toxicity and safety of Pet ether, chloroform and hydro alcoholic extracts of stem part of Coccinea grandis plant at $2000 \mathrm{mg} / \mathrm{kg}$ body weight dose.

From Streptozotocin induced hyperglycemic (chronic study) data, all extracts showed better tendency to decrease the blood glucose level on $14^{\text {th }}$ day of treatment. It was clear from hypoglycemic activity conducted on normal group of rats, the extracts has ability to lower the blood glucose level in normal group. Estimation has been conducted at $0 \mathrm{hrs} .1$ and half hrs. 3 hrs. and 5 hrs. Histopathological studies revealed the destruction of pancreas in STZ induced diabetic rat with intracellular gap, decreased cell density and altered architecture as shown in fig 1 . The diabetic rats treated by glimepiride (STD) and pet ether, chloroform and hydro alcoholic extracts indicated decreased intracellular gap, regain of architecture and increased cell density. Elevated level of lipid peroxidation in diabetic rats was controlled by standard glimepiride drug and all extracts.SOD and catalase activities were increased to normal level in diabetic rats because of antioxidant activity of pet ether, chloroform and hydro alcoholic extracts of stem Coccinea grandis plant. It revealed attenuation of oxidative stress.
Traditional plants contain flavonoids, phenolic compounds, glycosides, alkaloids. It was supported from ancient literature the medicinal uses of plants in different diseases. The plants rich in flavonoids, phenolic compounds, glycosides possess antidiabetic and antioxidant activities.

\subsection{CONCLUSION}

The present study showed the antidiabetic and antioxidant activity of pet ether, chloroform and hydro alcoholic extracts of stem part of Coccinea grandis plant in streptozotocin induced diabetic rats. These extracts showed promising reduction in blood glucose level in diabetic rats and reduces oxidative stress like standard glimepiride. Further studies are in progress to isolate bioactive constituents from Coccinea grandis stem extracts for antidiabetic activity. Further, exploration of biochemical mechanism involving antidiabetic activity needs to be done.

\section{ACKNOWLEDGEMENTS}

The author thankful to Annasaheb Dange, Founder President and Prof. R.A. Kanai, Executive director of Annasaheb Dange College of B. Pharmacy, Ashta for providing facilities and giving support to carry out this research work. This research did not receive any specific grant from funding agencies in the public, commercial, or not-for-profit sectors.

\section{CONFLICT OF INTEREST STATEMENT}

There is no conflict of interest. 


\section{FUNDING}

This research did not receive any specific grant from funding agencies in the public, commercial, or not-for-profit sectors.

\section{REFERENCES:}

1. Jayaprasad B, Sharavanan PS, Sivaraj R, Antidiabetic effect of Chloroxylon swietenia bark extracts on streptozotocin induced diabetic rats, Beni-Suef University J. Basic and Applied Sci, , 2016; 10: 61-69.

2. Surya S, Salam AD, Tomy VD, Carla B, Kumar AR, Christudas S, Diabetes mellitus and medicinal plants-a review, Asian. Pac. J. Trop. Disease, 2014; 4(5): 337-347.

3. Ullah A, Khan A, Khan I, Diabetes mellitus and oxidative stress- A concise review, Saudi pharma. J, 2016; 24: 547-553.

4. Balaraman AK, Singh J, Dash S, Maity TK, Antihyperglycemic and hypolipidemic effects of Melothria maderaspatana and Coccinea indica in streptozotocin induced diabetes in rats, Saudi. pharma. J, 2010; 18: 173-178.

5. Okokon JE, Antia BS, Udobang JA, Antidiabetic activities of ethanolic extract and fraction of Anthocleista djalonensis, Asian. Pac. J. Trop. Med, 2012; 2(6): 461-464.

6. Chowtivannakul P, Srichaikul B, Talubmook C, Antidiabetic and antioxidant activities of seed extract from Leucaena leucocephala (Lam.) de Wit. Agri. Natural Res, 2016; 50: $357-$ 361.

7. Arumugam G, Manjula P, Paari N, A review: Anti diabetic medicinal plants used for diabetes mellitus, J. Acute Disease, 2013; 2(3): 196-200.

8. Obafemi TO, Akinmoladunn AC, Olaleye MT, Agboade SO Onasanya AA, Antidiabetic potential of methanolic and flavonoid- rich leaf extracts of Synsepalum dulcificum in type 2 diabetic rats, J. Ayurveda and integrative med, 2017; 8: 238246.

9. Tamilselvan N, Thirumalai T, Elumalai, E., Balaji R, David E, Pharmacognosy of Coccinea grandis: a review, Asian Pac. J. Trop. Biomed, 2011; S299-S302.

10. Packirisamy M, Ayyakkanuu P, Sivaprakasam M, Antioxidant, antiglycation and insulinotrophic properties of Coccinea grandis (L) in vitro: Possible role in prevention of diabetic complications, J.Trad and compl. Med, 2017; 7: 54-64.
11. Munasinghe MAAK, Abeysena C, Yaddeighe IS Vidanapathirana T, Piyumal KPB, Blood sugar lowering effect of Coccinea grandis (L.) J. Voigt: path for a new drug for diabetes mellitus, Exp. Diabetes Res, http://dx.doi.org/10.1155/2011/978762.

12. Deokate UA, Khadabadi SS, Pharmacology and phytochemistry of Coccinea indica, Pharmacophore, 2012; 3 (3): 179-185.

13. Motiwala MN, Dumore MN, Rokde VV, Bodhe MM, Gupta RA Dumore NG, Danao, KR, Characterization and antioxidant potential of Coccinea indica fruit mucilage: Evaluation of its binding properties, Bioactive.Car.dietary.Fibre, 2015; 3: 6974.

14. Kabbaoui MEI, Chda A, Azdad O, Mejrhit N, Aarab L, Bencheikh, AT, Evaluation of hypoglycemic and hypolipidemic activities of aqueous extract of Cistus ladaniferus in streptozotocin induced diabetic rats, Asian Pac J Trop Biomed, 2016; 6(12): 1044-1049.

15. Kunga MR, Pachamuthu V, Chidambaram U, Natarajan,S, Elango B, Jaiganesh S, Antidiabetic activity of stem extract of Gymnema montanum in streptozotocin- induced diabetic rats, Food and Chem. Toxicology, 2011; 49: 3390-3394.

16. Abubakar A, Danjuma NM, Chindo BA, Nazifi, AB Antihyperglycaemic activity of tuber extract of Chlorophytum alismifolium baker in streptozotocin induced hyperglycaemic rats, Bulletin. Fac. Pharm. Cairo. Uni, 2018; 56: 60-67.

17. Murugesh K, Yeligar VC, Dash DK, Maiti, BC, Maity TK, Effect of Berberis tinctoria leaf (Berberidaceae) extract on antidiabetic, antihyperlipidemic and antioxidant status in streptozotocin induced diabetes in rats, Oriental Pharm and Expt. Med, 2006 ; 6(4): 336-343.

18. Ming S, Seymour Z, An improved spectrophotometric assay for superoxide dismutase based on epinephrine autoxidation, Analytical Biochem, 1978; 90: 81-89.

19. Nya Njomen GBS, Kamgang R, Oyono JLE, Njikam N Antioxidant potential of the methanol-methylene chloride extract of Terminalia glaucescens leaves on mice liver in streptozotocin-induced stress, Ind. J. Pharmacol, 2008.; 46(6): 266-270.

20. Gandhi GR, Sasilkumar, P, Antidiabetic effect of Merremia emarginata Burm. F. in streptozotocin induced diabetic rats, Asian Pac J Trop Biomed, 2012; 2(4): 281-286. 